and periodicals to a departmental library, with the explanation that there simply wasn't any more shelving space. In two weeks the required expansion was provided.

Gradually, by methods running the gamut of persuasion all the way from presidential ukase to subterfuge, univer- sity librarians are taking over the departmental libraries. Library schools are working toward the day when they will develop departmental librarians who are specialists in the subject itself as well as in its bibliography. It is a goal worth striving for, although in this feverish age it seems impossible of attainment.

\title{
A Handbook of Medical Library Practice
}

A HANDBOOK OF MEDICAL LIBRARY PRACTICE is in preparation by a committee of the Medical Library Association. Based on a preliminary manuscript by $M$. Irene Jones of the medical science department, Detroit Public Library, this book will be the result of the combined efforts of a group of medical librarians who are trying here to collect and present in orderly fashion those differences in material and procedures which distinguish a medical library from a general one. Their intention is to give chiefly the added information a general librarian needs upon entering the medical field. Far from being a complete manual of procedure, the volume presupposes some general knowledge of library methods and tools. It will form, as its title indicates, a supplementary handbook of special practices and reference equipment for medicine.

Particularly full treatment will be given subject headings, classification, reference books, rare books, and the history of medicine. The contents will comprise the following chapters: I. The medical library and the librarian, by Judith Wallen Hunt; II. Selection and ordering of books and periodicals, by Bertha B. Hallam; III. Cataloging, by L. Margueriete Prime; IV. Subject headings, by Isabelle T. Anderson; V. Classification, by Mary Louise Marshall and M. Irene Jones; VI. Reference, by Eileen R. Cunningham; VII. Pamphlets, pictures, microfilm, etc., by Eleanor Fair and Lillia M. D. Trask with the collaboration of Ethel Wigmore; VIII. Rare books and the history of medicine, by Chauncey D. Leake and Gertrude L. Annan.

This editorial committee, under the chairmanship of Janet Doe, hopes for publication in the spring of I94I. Inquiries may be addressed to the secretary of the association, Anna C. Holt, 25 Shattuck St., Boston. 